\title{
Revolutions, Religion and the Castle Hill Rebellion (1804)
}

\section{Introduction}

In 1804, the young British penal colony in Australia experienced its first and last fully-fledged convict rebellion at Castle Hill near Parramatta in New South Wales. The rebels were led by Irish political prisoners, though quite a few English convicts and former convicts joined their ranks. To all appearances, the rebellion was easily crushed by the immediate response of the authorities. Governor Philip G. King dispatched Major George Johnston with 53 soldiers and an unspecified number of members of a volunteer militia from Parramatta. After a brief skirmish, the surviving rebels either surrendered or were captured, and trials of the ringleaders followed in the next fortnight. In the light of the Irish participation, Australian historians currently stress the continuity of United Irishmen politics across the hemispheres (e.g. Hughes 1988; Karskens 2009; O’Farrell 2000; Silver 2002; Whitaker 1994). Undoubtedly, the prominent position of United Irishmen in the Castle Hill Rebellion and in earlier attempts running up to this event is notable.

A mere six weeks after the news of Emmet's 1803 rebellion in Dublin reached Australia, the Castle Hill rebellion responded (Whitaker: vii). Yet Irish ticket-of-leave convicts, who had established themselves on their farms and who, therefore, had something to lose in such a rebellion, joined in instead - puzzling scholars today (see e.g. O'Farrell: 37-38; Whitaker: 114). More than the news of an uprising in a very-far-away Dublin seems warranted to motivate such participation. Moreover, if indeed the rebels had had fighting experience in Ireland prior to their transportation, their breaking up and running away in the face of Major Johnston's line of soldiers is a remaining mystery that contemporaries were only too willing to see as Irish cowardice. Earlier attempts to explain the rebellion by the inhuman situation of the Irish convicts labouring at the government farms have been discredited as well (see Karskens 2009). In more general terms, to quote Jeffrey Alexander, "trauma is not the result of a group experiencing pain. It is the result of this acute discomfort entering into the core of the collectivity's sense of its own identity" (Alexander: 308). To fully explain the extent of Australia's Irish rising in 1804, more is needed than a consideration of the immediate grievance of transportation and its general conditions, an experience the Irish shared with all their English convict colleagues.

A full consideration of the actual situation of the Irish in New South Wales at the time, as well as a detailed look at the tenuous and conflicted relation between the United Irishmen rebellion in Ireland and the Australian convict uprising, will help clarify the events of the rebellion proper, which I will outline at first below. In the light of these considerations, then, the current explanatory model of the Castle Hill Rebellion - a primarily political one (see e.g. O'Farrell 2000; Silver 2002; Whitaker 1994) - will be complemented by two additional motivations, a religious and a judicial one. While the judicial focuses on the immediate context to the convict situation 
in the early colony, the religious might answer to the demands of understanding the core of Irish convict identity in Port Jackson. In combination, this triple causality helps to explain a famous relic, William Davis' Ecce Homo statue. Considered one of Australia's icons (Luck: 108-109), this small sculpture of Christ given as a present to the former convict William Davis has featured in a few studies (e.g. Suttor: 20; Whitaker 1996). Reading this statue's Irish Catholic iconography allows me to bring together recent historical research on the Irish Brotherhood rebellion and Irish Catholicism with well-known facts of the Castle Hill uprising.

\section{Historical Prologue: The Rebellion}

In 1798, from May to September, Ireland saw an uprising in nine counties against British rule. The rebellion was organised by the Society of United Irishmen, an association influenced by American and French republicanism. A belated French military intervention on behalf of the rebels, with 4000 soldiers, could not stem the tide of the military response led by General Charles Cornwallis on his first assignment after his less-than-glorious return from America. 780 Irish were transported between 1800 and 1802 to Australia (Whitaker: 24). Governor King complained in anticipation to his superiors that these Irish convicts were uniformly "the most desperate and diabolical characters" (qtd. In Whitaker: 24), and to all appearance they tried hard to live up to his expectations. The HMS Minerva (arriving in January 1800) brought the first load of Irish rebels with Father Harold sentenced for sheltering a wounded rebel, and General Joseph Holt, a rebel leader, whose hopes of giving information to the British in exchange for an absolute pardon, had been fooled after his arrest. In February 1800, the HMS Friendship transported Father Thomas Dixon, a loyalist himself, for his family's involvement in the Wexford rebellion. With a little over 200 transported Irish in these first two shippings the stage was set for unrest in New South Wales.

There are three precursors to the actual Castle Hill Rebellion in 1804, which not only present some of the cast of the rebellion already but also show the strategies the colonial authorities favoured in responding to such a challenge. In part these strategies were repetitive - whenever the authorities felt they were in charge of the situation - in part, however, they exacerbated the conflict. In turn, the actions of the individuals later concerned in the Castle Hill Rebellion are also traceable through the climactic developments towards the rebellion itself in these three abortive attempts.

The first rebellion was planned for Sunday $31^{\text {st }}$ August, 1800 at Toongabbie government farm, a colonial plantation run by convict labour. The plan was to secure Parramatta, killing Reverend Samuel Marsden, Paramatta's magistrate and the Anglican pastor of the penal colony. Then the rebels planned to march on Sydney, there to kill Governor John Hunter (who was due to leave the colony) and Lieutenant-Governor Philip G. King (who had already arrived to replace him). In Sydney they hoped to take over the HMS Buffalo with the help of disaffected sailors, and sail for France. Reverend Marsden received a letter warning him of the plot, so it did not eventuate.

Governor Hunter installed a Commission of Enquiry under the future Governor King, a step suggesting not so much a willingness to ease King into his administra- 
tive duties as Hunter's desire to escape from being implicated in such troublesome issues himself. Hunter had been recalled in all-but-disgrace and would not have wanted additional troubles to cloud his reputation (he vindicated himself successfully upon his return to London). The Commission "was unable to prove that any of the alleged conspirators was actually guilty of sedition" (Silver: 30), a finding that did not stop sentences of excessive floggings for all suspects involved. Father Harold, suspected of involvement and questioned, refused to reveal names though he admitted knowledge of the plot. He was exiled to Norfolk Island with the ringleaders. Also in response, Governor Hunter formed the Loyal Sydney Association and the Loyal Parramatta Association militias, drawing upon the male free civilian population to support the military.

Before the sentenced and exiled could even be transferred to their new destination, a second rebellion attempt was to hit Parramatta on Sunday $28^{\text {th }}$ September, 1800. The target now was to converge upon the Anglican church service of Marsden himself and "put to death all the gentlemen among the military" (Silver: 38), then liberate those imprisoned for the last attempt, and together starve or fight Sydney into submission, to escape eventually by ship. Again, Reverend Marsden was informed in time, on the $27^{\text {th }}$, by his convict shepherd. In an attempt to arrive at pikes and muskets, which Reverend Marsden suspected were still hidden away from the first attempt and ready to be used now again, he and Judge Atkins ordered the flogging of two suspects (Silver: 41), to no avail.

A Commission of Enquiry set up by Governor King did not find enough evidence for a capital charge but all involved convicts received excessive flogging sentences; amongst these was William Davis - he of the later statue gift. The ringleaders were to be transported to Norfolk Island. In January 1801, an Active Defence group was formed to supplement the Loyal Associations (Silver: 47). Apparently, King considered the measures taken by Hunter in response to the first rebellion attempt to have been the right in all details - thus the repetition in quality - though not efficient in quantity. Despite Governor King urging the government in London not to send any more Irish rebels, the HMS Anne arrived in February 1801, bearing Father O'Neal/ O'Neill, another Catholic priest, who was preventively transported to Norfolk Island. The colonial administration's nervousness seems to have abated half a year later. It extended conditional pardons for well-behaved convicts - amongst those also rebels who had been involved in the two riots - in celebration of the Union of Great Britain and Ireland in 1801 and of the King's birthday (4 June 1801). In July, indeed, the militia was disbanded. Governor King opened a new government farm at Castle Hill in the district of Parramatta with 300 convicts. Then, eight months later, on $26^{\text {th }}$ March 1802, an informant alerted Reverend Marsden to a third rebellion plan.

The targets this time were Reverend Marsden, yet again, the Sydney executioner Richard Rice, and Mr Cox, a farmer and General Joseph Holt's employer, thought to be an informer. In this, as Whitaker has shown conclusively, the rebels were mistaken: Holt himself, in character with his earlier attempt in Ireland to ingratiate himself with the authorities before his transportation, was the actual government spy (Whitaker: 113). Once Parramatta was taken, the rebels wanted to ask the soldiery to change sides and planned to force those who refused to march as human shields at the front of the columns into Sydney. A requisitioned ship would then be sent to rescue those rebels who had by now been indeed transported to Norfolk Island. 
The Enquiry Panel once again was set up and sentenced two ringleaders to be flogged. It appears, however, that no additional strengthening of the military was thought to be necessary this time around; the authorities felt themselves secure in managing the rebellion attempts by tried and tested means.

In 1802, HMS Atlas I, Atlas II, and Hercules brought up the numbers of Irish convicts in the colony to over 1200, about a third of the entire population. In a public relations disaster, the end of 1802 further saw Father O'Neal released from Norfolk Island on orders from England as innocent. On the $20^{\text {th }}$ April 1803, after receiving a dispatch from Lord Hobart that suggested the Catholic convict priests be used to educate the convicts and minister to their spiritual needs, Father Dixon was chosen by Governor King to serve as Catholic priest within a very definite set of regulations. He was the only choice, with Father Harold still in Norfolk Island and Father O'Neal already returned to Ireland. Father Dixon took an Oath of Allegiance and Abjuration, and received in turn 60 Pounds annual salary. So the first Catholic Mass was said in Sydney $15^{\text {th }}$ May 1803, fifteen years after the arrival of the First Fleet, and eleven years after the first petition for a Catholic priest submitted by Irish Catholics in Australia to the authorities in 1792 (Suttor: 16). Governor King reported back to England that this decision had "the most salutary effects on the numbers of Irish Catholics we have and since its toleration there has not been the most distant cause of complaint" (qtd. in Whitaker: 93). His relief was to be famously premature.

On the 22 $2^{\text {nd }}$ January, news of Robert Emmet's 1803 rebellion in Dublin reached New South Wales (Whitaker: vii), and a mere six weeks later, on Sunday $4^{\text {th }}$ March 1804, at 7 p.m., a convict hut was set alight at Castle Hill government farm as a signal for the rebellion to begin. ${ }^{1}$

The password of the Castle Hill Rebellion was "Saint Peter"; the rallying cry that of the Wexford rebels, "Liberty or Death", in some renditions with the added "and a ship home". The leaders were Phillip Cunningham, a stonemason and overseer at the government farm, and William Johnston. Both were men with military experience and United Irishmen. They sought the leadership of Joseph Holt, who did not turn them in yet but did not help either, deciding to wait it out. So when the Castle Hill Rebellion started in the evening, its first target was Robert Duggan, the executioner and flogger of the Castle Hill farm, who escaped death only because the pistol fired at his face did not go off. Most convict constables and overseers joined the rebels who started raiding the farms in the vicinity for additional weapons. This netted them about one-third of the colony's armoury. They also gained new supporters. The Loyal Association called together at Parramatta in response feared an immediate attack by the convicts who were seen gathering on nearby Constitution Hill, just above the town. Reverend Marsden immediately left for Sydney by boat, with his wife and three other women and their children. The convict ranks were reputed to be above 400 men at this point. Cunningham apparently drilled his convicts in the early morning hours and then marched towards the Hawkesbury, hoping to swell the insurgents' ranks with Irish Catholic settlers, who formed the majority of the population on the Hawkesbury. They were to next take Parramatta, kill Reverend Marsden (a constant part of any rebellion plan so far) and any military not join-

1 The uprising is very well researched, and the following details are a compilation from various historiographic sources. 
ing them, and move on to Sydney. Once Sydney's garrison had been overcome, the rebels hoped to requisition a ship to reach France, yet again another constant.

In Sydney, the alerted Governor King despatched 52 rank and file led by Quartermaster Thomas Laycock Sr, a notoriously violent man, who was discharged from his service as mad in 1806 (Statham: 308). Leaving Sydney barracks alerted, and the militia assembled, the Governor himself rode to Parramatta, giving Major George Johnston command over the military on the way. Like King himself, Johnston was a veteran of the American War of Independence. In the early morning, Governor King and Major Johnston arrived in Parramatta, and King proclaimed martial law, giving his written orders to Johnston, which included shooting anyone who attempted to flee when challenged.

On Constitution Hill, Major Johnston, the infantry and some members of the Parramatta Association found nobody and were thus forced to begin a pursuit into the very hot Monday, towards the Hawkesbury, which ended in the afternoon when the rebels were only about one mile ahead of the exhausted military column. Johnston first sent his trooper ahead, waving a white handkerchief. To slow down the rebels, he was to tell them the Governor was on his way, and they should give themselves up; he returned without his weapon, which the rebels had taken off him. Johnston next sent in Father Dixon (there is no explanation as to where Father Dixon came from but all sources note his presence) to ask them to disarm and give themselves up; Father Dixon failed in this. Upon which Major Johnston rode up himself with his trooper, demanded to see the leaders for negotiations, and returned to bring Father Dixon a second time around. While they were all talking at this second meeting, the troops finally caught up with the convicts and appeared between the trees. At which Major Johnston clapped his pistol to the convict Johnston's head, instantly imitated by his trooper who did the same to Cunningham, and both dragged their prisoners towards their lines, where Major Johnston then ordered his men to fire on the rebels (Whitaker: 108). This initiative of Major Johnston ensured not only an element of surprise and tipped the scale in favour of the army, it was also very much against the rules of war and may have been owed to his somewhat cynical, veteran outlook. The fire exchange took about fifteen minutes, with Johnston noting later that the rebels were not really returning fire and dispersing very quickly. A few were then pursued into the bush and killed in reprisals. The pursuit ended at 4 p.m. (Silver: 105), when some of the last rebels were taken prisoners. Quartermaster Laycock at some point in this skirmish wounded the unarmed Cunningham, who was still unconscious when summarily executed by Major Johnston on Tuesday (Silver: 106). Free settler militia and English convicts then joined in the mopping-up. Fifteen convicts were eventually dead, over 300 surrendered.

On $8^{\text {th }}$ March, nine rebel instigators stood trial, and all were sentenced to death. Reverend Marsden was shocked to find that four of these were Protestants. Seven rebels were flogged 200 to 500 lashes each and 34 (including those flogged) were sent to the Hunter River coalmines, a place of secondary punishment. Father Dixon's permission to read Catholic mass was withdrawn but he continued to minister secretly until leaving the colony four years later to be replaced by Father Harold. ${ }^{2}$ Joseph

2 This can be concluded from his application to the Evangelisation Congregation in the Vatican of $19^{\text {th }}$ April, 1804, in which he stated he had been administering the sacraments for two years (qtd. in Wiltgen: 183), which predates his official instalment as the colony's Roman Catholic priest. It is not likely, therefore, that by losing this official British status he would have changed his behaviour. He had, as Wiltgen points 
Holt was arrested $21^{\text {st }}$ March, and the investigation revealed he had informed of the rebellion. He was then sent off to Norfolk Island. The Militia had been disbanded, a sure sign of the authorities considering the matter well and truly settled.

\section{Structural elements}

The individual targets sought by the rebels in the various run-ups as well as in the Castle Hill Rebellion proper always represented three elements: the colonial administration, its judiciary, and the Anglican faith. It is the complex structure of their objective that shows the triple causality leading to the Castle Hill Rebellion, a feature still awaiting its full appraisal. Thus, added to United Irishmen politics imported from Ireland and targeting the British colonial administration, the second motivational force of the rebels appears evidently that of a perceived miscarriage of justice. It is closely tied up with a third, motivational force, which, I suggest, is Irish Catholicism. As an element of the 1800-1804 rebellions, Catholicism has been largely ignored in contemporary Australian historiography on the ground of two arguments that are repeated incessantly, neither of which, however, holds up to close scrutiny. The first of these arguments is the interreligious character of the leaders of the 1804 rebellion; the four Protestants amongst the nine men that were hung. This is seen as proof of the continuity of 1804 with the United Irishmen of 1798, in their enlightened, republican, secularized focus on national Irish unity across the religious divide. ${ }^{3}$ Yet we have no information of the 300-something other participants' denominations and are thus left to guess whether the Catholic/Protestant proportion of the Castle Hill leadership is in fact representative of the group as a whole. There are reasons why it might not be.

By 1798, the extent to which Catholic Defenders had joined the United Irishmen has prompted some Irish scholars to speak of a Catholic take-over of the movement (Atkin: 268). To the Australian colonial government, such intricacies of Irish alliance mattered little. Yet to us the possible involvement of Defenders, with their pronounced "self-consciously sectarian", read: militant, Catholicism (Bartlett: 260), amongst the 1804 rebellion is noteworthy indeed. The password of "Saint Peter" has been seen as in general terms referring to the rebels' religion (Whitaker: 93-94) but might as well be a reference to the so-called Defender Catechism, a question-and-answer password, in which "Saint Peter" features very prominently. One 1795 example, found in Leitrim, reads:

Q. What do you design by that cause?

A. To quell all nations, dethrone all Kings, and to plant the true Religion that was lost at the Reformation.

Q. Who sent you?

A. Simon Peter, the head of the Church.

Signed, "By Order of the Chief Consul” (qtd. in Garvin: 231)

out, been made Prefect apostolic of the Prefecture apostolic of the Missions of New Holland in 1804 as well (by the Vatican) and would have considered this his actual instalment rather than King's toleration or its later withdrawal.

3 This is, for one, the position of Whitaker's seminal study of the Castle Hill Rebellion cf. Whitaker, 1994; see for an even more extensive view, "transcend[ing] ethnicity, calling and rank", Karskens: 293. 
Garvin notes, quite correctly, that this rebel Catechism derives its sentiments from the French revolution, replacing e.g. "Tree of Liberty" with "true Religion" in the first answer (Garvin: 231) but still keeping to a contemporary French (Consular) republican model. As "agrarian terrorists" (Reece: 41), Defenders would be comfortable with hit-and-run tactics. Overcoming constables, firing huts, plundering farms for weapons and ammunition were all within their scope of experience. Facing down a disciplined professional soldiery's firing line was not their strategy. The behaviour of the Castle Hill Rebels thus indicates less professional military experience and more the presence of Defenders who acted deliberately from ambush.

The second line of argument goes beyond such details, and claims a largely irreligious and illiterate Irish peasantry in the eighteenth century (e.g. O'Farrell: 39; Suttor: 18). In this, Australian scholars basically take up mid to late twentieth century Irish historians' view of a pre-Tridentine church in Ireland in the eighteenth century, with a peasant faith incomparable to the post-Famine devout revolution. However, this claim, itself based on the assumed conflict between a national Irish versus a Roman Tridentine devotional practice, has been substantially qualified by recent research into eighteenth-century Catholicism in Ireland (see, for example, Carroll: 150; Hachey: 15). Moreover, Australian scholars' failure to consider the level of education provided by illegal hedge schools in Ireland (cf. MacManus), or the rise of a Catholic press in the second half of the eighteenth century presents an inadequate picture of the Irish convict population. The extent to which "illiteracy" in the late eighteenth century Gaelic-speaking peasantry of the southern counties, as noted by Ian McBride, was then measured by their (in)ability to read an English Bible (in Latin script as well as in a foreign language!) or more strictly by their (in)ability to write, while rural teaching was reading-based, has not been fully considered to date (McBride: 57). All of which should help lay the spectre of the generally irreligious and ignorant Irish peasant to rest. ${ }^{4}$

Reintroducing Catholicism into the Australian picture is not a currently fashionable position in eighteenth century criticism, where, to quote Roger Dupuy writing about the peasant rebellion in the Vendée, "l'historiographie se dégage de l'optique étroite qui accordait au problème religieux une importance primordiale dans le processus du soulèvement". (Dupuy: 113) ["Historiography disengages itself from the focus that granted to religious problems a primary importance in the staging of a rebellion". - Translation TM] Possibly, the swing of the pendulum into an all-secular explanation in Australia is also a reaction to the ultramontane takeover of both the iconic years of 1798 and 1804 especially in the late nineteenth century historical writings of Cardinal Moran. Yet the dismissal of religion, a defining feature of Irish eighteenth century categorization (of self and of other, cf. McBride: 12) may be too hasty, leaving, as it does, several elements of the rebellions, both the Irish and the Australian, unexplained - not least of all the involvement of the Catholic clergy. Additionally, including a critical re-evaluation of the Catholic perspective of the Irish convicts - not a mere rehashing of ultramontane arguments in favour of Irish martyrdom - opens a glimpse into the genesis of a counter-memory ${ }^{5}$ to the Austral-

4 This might also help explain the note that was sent around by Cunningham with the rebellion password to alert sympathizers, which puzzles Whitaker who cannot explain why such a note should be sent when the Irish convicts were illiterate (Whitaker: 93-94). They might have been able to read though not to write.

5 "The master commemorative narrative represents the political elite's construction of the past, which serves its special interests and promotes a political agenda. Countermemory challenges this hegemony by offering a divergent commemorative narrative representing the views of marginalised individuals 
ian master narrative of the Irish minority's reluctant but inevitable move towards a unified progressive and enlightened Australian nation.

\section{Re-evaluating a Catholic perspective}

To start, then, with the immediate response to the judicial situation in the colony: the convicts transported from Ireland following 1798 had legitimate grievances and could indeed claim a miscarriage of justice. No papers were sent with the convicts, shipload after shipload, thus - in the absence of indictments (Whitaker: 23) - colonial authorities assumed the worst of every Irish convict. In turn, naturally, all could claim unjust treatment, even the odd thief. Yet, as the courts martial and assizes following 1798 did indeed, even in official parlance, stand accused of "irregular procedures" (see Silver: 6, 7; Reece: 243; O'Farrell: 28). This phrase means summary justice with no recourse to the law, sentences based on defamation or suspicion, and tortures to extract confessions. The lifetime sentences simply assumed by the Australian authorities were most questionable. Governor King could have erred on the merciful side but as his assumption in the case of Father $\mathrm{O}^{\prime}$ Neill shows he tended not to. ${ }^{6}$

O'Neill/Neal had been given 250 lashes to confess to his knowledge of a plot leading to the murder of a Loyalist spy and, when that had failed, he had been drugged to induce him to sign a ready-made confession (Silver: 19). After his transportation and arrival in New South Wales, Governor King considered him "of most notorious, seditious and rebellious principles", 7 simply on the grounds of being a Catholic priest, and preventively exiled him to Norfolk Island. As mentioned earlier, O'Neill was found to be innocent when his case was reopened and allowed to return home at the end of 1802 on instructions from England (Silver: 70). In a nutshell, O'Neill's precedent did nothing for the Australian authorities' standing with their Irish convict population. It would have come across as (what it was) an admission of judicial error, yet in one case only. So what of the rest?

Convicts considered gentlemen were again and again treated differently by the colonial system, and they were consequently often suspected by the convicts of being collaborators. In the case of Holt, as has been shown, this suspicion was wellfounded. It is no surprise then, to find the second failed rebellion attempt calling for the death of all gentlemen among the military. British justice for everybody else, when it was seen in New South Wales under Governor King, did not look well either.

One has to turn to a legal historian at this point, as other Australian historians have been strikingly coy to express the situation. In his seminal A History of Criminal Law in New South Wales, Gregory D. Woods states: "Marsden's period as a magistrate at Parramatta coincided with excess and illegality in punishments. [...] Practices akin to torture do not sit comfortably with the profession of the teaching of Jesus Christ";

and groups within the society. [...] While this conception of countermemory shares Foucault's emphasis on its oppositional and subversive character, it departs from his insistence on the fragmentary nature of countermemory. Countermemory is not necessarily limited to the construction of a single past event; it can be part of a different commemorative framework forming an alternative overview of the past that stands in opposition to the hegemonic one". (Zerubavel: 241)

6 Compare to Governor Hunter's more understanding stance in his letters, qtd. in Moore: 134: “The manner in which the convicts are sent out from Ireland is so extremely careless and irregular that it must be felt by these people as a particular hardship, and by government as a great inconvenience".

7 Qtd. from Historical Records of Australia, Series I, Vol. 3, p. 9. 
and he cautions: "This use of torture in the history of New South Wales Criminal law should not be forgotten" (Woods: 44). In such conditions, Father Harold's noted recalcitrance in cooperating with the authorities before the actual 1804 rebellion got him transported to Norfolk Island. In contrast, the striking clemency that Father Dixon met with after 1804 would have compromised him in the eyes of his parishioners. "In Ireland, history is never forgotten, for in the present, the Irish merely relive a horrible past" (Nolan: 36). The colonial authorities' brutal suppression of any attempted or only rumoured rising from 1801 to 1803 gave Irish convicts over to military justice, which by its harsh flogging regime repeated the Irish experiences of 1796-98. All of this was obviously enough to start a rebellion among those politically minded amongst the convicts, but the violent issue had to be brought still closer to home for the participation of the larger, already settled Irish population of New South Wales.

Early colonial New South Wales was not only a social system dominated, indeed run by the military, ${ }^{8}$ it was a "confessional state". ${ }^{9}$ It was a conservative Anglican system, even by the standards of the day, ${ }^{10}$ enforcing outer conformity as an expression of national unity: King and Church. To those of a lax or irreligious orientation amongst the convicts or settlers, enforced outer conformity was no problem. To practicing Catholics it was impossible, forbidden under threat of excommunication since $1704 .{ }^{11}$ There are diverging views of the extent to which church service attendance was enforced. By his 1803 order to confine all people found loitering in the streets in Sydney or Parramatta during the hours of divine service (King: 134), Governor King had very decidedly closed a possible loophole just before the rebellion. ${ }^{12}$ After Castle Hill, apparently, Irish convicts would be marched to the church but spared the actual attendance, remaining outside the building for the duration of the service (McGovern \& O'Farrell: 7). The very existence of this response indicates the authorities' need to compromise in the face of continuing and substantial Irish Catholic resistance.

Another indicator of Catholic resistance to enforced Anglican conformity is the Irish convict population's refusals of Anglican baptisms, marriage rites or burials. ${ }^{13}$ These issues provoke large misunderstandings in current criticism, such as the anachronistic claim to a Catholic lay church prior to 1820 in Australia (Morley, Catholic Weekly: n.p.). Few scholars seem aware of the extent to which sacramental powers accrued to the Catholic laity in the Tridentine reforms. In the absence of priests, marriage ${ }^{14}$ was easily performed. The clergy's function was merely to bless

8 "a dictatorship, more or less benevolent" (McGovern \& O'Farrell: 1).

9 I am somewhat disingenuous in quoting from Gascoigne (20), whose original statement qualifies this phrase a little. As he states it, the early colony's "outward forms bore the imprint of a confessional state where membership of the church and of the body politic were synonymous". If one considers, however, that the colonial penal state in NSW consisted as such of outward forms (e.g., rituals and spectacles of various hierarchical levels of cooperation, coercion, control or punishment), the actuality of a confessional state in colonial NSW is evident and needs no qualification.

10 George III's Act for the Relief of his Majesty's Roman Catholic Subjects (1791) was only adopted in NSW in 1830 (Callaghan: 108). The delay is that of a generation's lifetime for the experience of Irish convicts.

11 Collectanea S. Congregationis de Propaganda Fidei seu Decreta Instructiones Rescripta pro Apostolicis Missionibus (Rome: Typographia Polyglotta, 1907), Vol. I, n. 267, p. 91.

12 "[...] the governor [King] was very strict about observance of the sabbath". (Silver: 34; similarly 52)

13 This refers to the burial of an Irish convict named Burn, who in 1792 had petitioned for a priest, after a wake next to his hut. According to Marsden "in the most beastly manner, after the most horrid oaths, curses and imprecations" (qtd. in Quinn: 19).

14 The Trinitarian definition of the sacrament of marriage consists of mutual, openly declared and witnessed bonds between a Catholic man and woman: In order that the different parts of this definition may be better understood, the pastor will teach that, although a perfect marriage has all these conditions, viz. internal consent, external assent expressed by words, the obligation and tie which arise from the 
a sacramental union achieved by both partners and such a blessing could be postponed till a priest would become available. Fast, private burials next to convict huts enraged Reverend Marsden as "most beastly", yet to a Catholic, such a burial was preferable to the unhallowed grounds of a heretical church. The situation is even clearer with baptism, which the Tridentine Catechism explicitly declares a sacrament that will and should often be given by women (Vol 2. Chap. 2/ n. 12, p. 125), and that, in Catholic theology, does not need the presence of a priest either to be legitimate. This is a markedly different concept to the reformed notion of baptism as the basis of an Anglican community, with the infant "grafted into the church" - as this quote is from the Articles of Faith, ${ }^{15}$ the church in question is naturally the Anglican one by a registered baptism in their respective parish.

Needless to say, once a Catholic priest arrived after decades of absence, he would have his hands full acknowledging and blessing past sacramental status, not to mention that the lack of some form of centralised registration in the case of marriage paved the way to abuses such as bigamy. It is in this context that the often-quoted contradiction between Father Therry's 1820s complaints of the unblessed state of his congregation and Father O'Flynn's earlier triumphant reports of the persistent refusals of Anglican baptism, marriage rite and even the solemnity during the enforced church services (e.g. Suttor: 19) resolves into two sides of the same coin. ${ }^{16}$

That Anglican baptismal records are indeed no mirror of the actual baptisms performed amongst the Irish Catholics is apparent in Governor King's demand that Father Dixon should register his baptised flock (and King's obvious relief at such an opportunity to set his records straight): "Remarks - The Births are uncertain and not easily Collected from the Scattered state of the Settlers' Allotments, and Children born of Catholic Parents and not Baptised will be remedied now, as the Priest will keep a Register of the Baptism". (qtd. in Morley: n.p.). To the Anglican governor, children not baptised and registered by Reverend Marsden into the Anglican church, would of course be considered "not Baptised". No register kept by Father Dixon has so far been found.

By refusing the Anglican marriage service, however, the Irish convicts would blend in more easily with the common law marriages that were practiced by English convicts and officially and ardently denounced as concubinage by Reverend Marsden (Quinn: 51). Official views would not (indeed could not) account for such distinctions of doctrine and faith. In the case of the Parramatta district's records, run by Reverend Marsden, one can expect an additional complication. As missionary-minded evangelical pastor, Marsden refused to accept that Irish Catholics were not a part of his congregation or responsibility. As "racially" prejudiced against them, ${ }^{17}$ Marsden could only read the Irish defiance that his proselytising efforts regularly met with as diabolical. In his turn, he declared the Irish irredeemably damned. ${ }^{18}$ This is echoed in his famous repeated diatribes against Irish convicts, and in his uniform consid-

contract, and the marriage debt by which it is consummated; yet the obligation and tie expressed by the word "union", alone have the force and nature of marriage" (Catechism of the Council of Trent: p. 226). Later pages stress the need of pastors to enforce in their congregation an understanding of the necessity of witnesses and a priest to give full form to the legitimacy of marriage, which however rests in the union of the two partners already.

15 XXVII “Of Baptism”. Articles of Religion, The Book of Common Prayer, 705.

16 Suttor (19) notes that there was no open disobedience in the military; the Catholics in the 48th regiment always attended. By implication this makes the attendance amongst the convicts more doubtful.

17 Qtd. in O'Farrell, 39: “the most wild, ignorant and savage race"; in 1807 letter to London Missionary Society.

18 Qtd. in O'Farrell, 39: "no true concern whatever for any religion [...] should the catholic religion be tolerated $[. . .]^{\prime \prime}$ 
eration of Catholic marriages as a state of concubinage. ${ }^{19}$ Marsden saw criticism of the Anglican faith as criticism of the state (in all its implication) and, worse, as criticism of the very position which he embodied. He did not tolerate either secular or spiritual criticism.

In short, far from the notions of an irreligious peasantry or an anti-clerical lay church, there was room for the Irish Catholics in early New South Wales to maintain a Tridentine faith in the face of what looked to them like insistent religious persecution. It should not surprise anyone then, as it does $\mathrm{O}^{\prime}$ Farrell for example, that Catholics flocked to the clergy after 1820 in numbers that stunned authorities and priests alike (O'Farrell: 40).

Some historians read Governor King's appointment of Father Dixon as an enlightened concession of Catholic relief; in fact he has even been accused of being much too lenient in this measure (King: 121). It is indeed surprising in its extent considering the rapprochement between King's devout wife and Reverend Marsden (King: 50) as well as King's own stout Anglicanism. ${ }^{20}$ It is also, however, a conciliatory gesture with strategic intent. Governor King improved the fortifications of Sydney harbour against the threat of a French invasion, ironically by using as forced labour those very rebels sentenced after the first unsuccessful Irish convict rebellion in 1800 who had hoped to escape to France (Silver: 44). He thus created outward defences with the help of the enemy within the colony. The defence against the enemy within, as King undoubtedly perceived the Irish in New South Wales, ${ }^{21}$ consisted of concessions to their Catholic faith. Yet far from being too lenient, King was too reluctant in granting these strategic concessions.

In contrast to Lord Hobart's directives, ${ }^{22}$ Governor King did not agree to allow Father Dixon to teach his charges (see his letter to Lord Hobart $9^{\text {th }}$ May, 1803 ${ }^{23}$ ), which meant that the future generation was to be taught Anglicanism in order to be assimilated. Eventually, this would eradicate Irish Catholicism in New South Wales in

19 One of the consequences of Marsden's attitude towards Catholic "concubinage" can be observed in King's establishment of an orphanage, opened on 17 August, 1801, which seems very much a pet project of his wife and Reverend Marsden (who were both running the institution, nicknamed "Mrs King's orphanage"). This abolished the more confessionally neutral "boarding out" model of earlier governors. Far from containing only orphans, girls from concubinage backgrounds were forcibly removed from their morally dubious parents and boarded behind an eight-feet-high stone wall that was erected in Jan 1805, surrounding the orphanage to inhibit illicit contact between the parents and children. 103 girls were in this institution by May 1803. "The children are to be entirely secluded from the other people, and brought up in habits of religion and morality..." as a letter by Mrs. Paterson states (qtd. Bubacz: 68), clarifying that "habits of religion" indicate Marsden's version of Anglicanism. "Establishing an asylum allowed King the potential to 'exile' a large proportion of the young female members of the colony and this withdrawal could be seen as a penalty to the rest of the community and as an opportunity to reform and re-educate the individuals removed". (Saltmarsh: 3 )

20 King calls him "a religious man with deep convictions" noting his efforts to "increase public piety" (134). Yarwood is less lenient: "King's despatch reveals with quite breath-taking candour the flaws of the religious policy he carried on from Hunter in attempting to dragoon unwilling congregations to hear the word of God. [...] King saw the state's power as enforcing church attendance and an outward show of virtue. In each case, church and state were regarded as reinforcing each other; the clergy were moral policemen, not evangelical pastors who preached for individual believers the gospel of a loving Christ". (Yarwood: 83)

21 "He had written to the British government about the establishment of batterys [sic!] that 'completely prevent any attack from without' but had argued that 'our exertions must soon be turned to securing ourselves from any attempts of the Irish republicans."' (King, qtd. ibid. : 110)

22 29.8.1802, Historical Records of Australia, Series I, Vol. 3, p. 564.

23 "To employ them as schoolmasters would be giving them the means, were they so disposed, of instilling improper ideas into the minds of their pupils. However, I do not think that would be the case with Dixon $[\ldots .$.$] . I believe it will be admitted that no description of people are so bigoted to their religion and priests$ as the lower order of the Irish, and such is their credulous ignorance that an artful priest may lead them to every action that is either good or bad. The number of this description now in the Colony is more than a fourth of the inhabitants. They have frequently felt uneasy at being excluded from exercising their religion, which has been heightened by the idea of having priests among them who are forbid preaching to them'”. Historical Records of Australia, Series I, Vol. 4, p. 83. 
the long run. The Hawkesbury-Sydney-Parramatta circuit allowed to Father Dixon resulted in practice in a Catholic clerical presence one Sunday every three weeks, not exempting the Catholics from the obligatory regular Anglican church service on the other Sundays. To further enforce this regular obligatory attendance, King explicitly forbade Catholics to travel on Sundays to a Catholic mass not in their district. ${ }^{24}$ Baptisms and marriages would now be in Dixon's charge, yet there was little possibility of extreme unction or a last confession to the dying unless they managed to die in accordance with Dixon's travel calendar. Catechising as a form of teaching was forbidden, thus in practice making a clerical preparation for the First Communion or Confirmation impossible.

In short, Governor King's concession was too little and too late. It maintained the basic problem, that of an enforced Anglican conformity, in the eye of ultimately unavailable relief. Father Dixon's taking of the Oath of Allegiance and Abjuration and accepting his $£ 60$ salary only must have made him look complicit to this scheme. The assumption that Major Johnston brought Father Dixon along as a decoy to his dealings with the rebels, in fact to gain him enough time for his columns to catch up while pretending to negotiate, points to the authorities' awareness of a religious element in the uprising. As well, it points to the lack of spiritual authority, which Father Dixon could ultimately claim over his charges. In a nutshell, it embodies the dilemma of Father Dixon's role as mediator. Dixon's subsequent loss of position and indulgence mirrors that he had failed to act according to the colonial government's plans. This was not about granting one-third of the population their right to practice their faith in an enlightened view of minority rights, this was a concession to prevent imminent rebellions. As the concession had failed, it was withdrawn. ${ }^{25}$

\section{Symbolism, Iconography, and the Enlightenment}

In evaluating the impact of the Enlightenment on the early Australian colony, it is easy to be impressed by the experiment of convict transportation to create a civilized settlement - today's metropolis Sydney. Amidst the celebration of enlightened ideas of educating the criminal classes to a life of productivity, cleanliness and moral improvement (cf. Gascoigne: xi-xii), the treatment accorded to the early Irish convicts and their Castle Hill Rebellion is a timely reminder of Pocock's different Enlightenments theories, developed further, for one, in 2004 by Gertrude Himmelfarb. Not some abstract or French philosophical concept of the Enlightenment was transported to Australia, but a very Anglican version of it, actually even retrograde in development compared to the British contemporary situation such as seen in the acts of Catholic relief of 1791. Between the structural pillars of church and King no middle way across denominational lines and cultural borders was intended in Australia. Judging somewhat anachronistically by today's definition of the United

24 “3. As Mr. Dixon will be allowed to perform his clerical functions once in three weeks at the settlements of Sydney, Parramatta and Hawkesbury, in rotation, the Magistrates are to strictly forbid suffering those Catholics who reside at the places where service is not performing from resorting to the settlement and district at which the priest officiates for the day". REGULATIONS TO BE OBSERVED BY THE REVEREND MR. DIXON, AND THE CATHOLIC CONGREGATIONS IN THIS COLONY - ISSUED BY GOVERNOR PHILIP GIDLEY KING ON 19/4/1803. See: Historical Records of Australia, Series I, Vol. 4, pp. 104 -105.

25 Since King ordered (12.4.1803) all Catholics to be registered with name and address prior to indulging Dixon, control of those who had registered was quite easy afterwards. 
Nations, an ethnic community is threatened with cultural genocide if its population is forcibly removed, if its cultural and religious practices are suppressed by legal or administrative means, and if they are exposed to propaganda against them. ${ }^{26}$ All three features clearly applied to the majority of Irish convicts in Australia at the turn of the nineteenth century. This resulted in an Irish discourse of victimisation, in which a statue of Christ could become emblematic for the Irish convicts' fate.

A close iconographic reading of this statue shows the confluence of political, religious and judicial motivations behind the Castle Hill Rebellion. As one inscription states, it was "presented to William Davis in 1817 by his fellow colonists in sympathy for the sufferings he endured for his faith" (qtd. in Whitaker: 36). The seemingly obvious narrative of a martyrdom of William Davis, who was one of the convicts sentenced to 200 lashes in October 1800, is the focus of current views of this statue and its inscription. Anne-Maree Whitaker, however, has significantly dated the inscription to 1951 (37). The iconography of the statue itself tells a more complex story than the ultramontane reading as a relic of Irish martyrdom which this belated inscription tries to fix. It is not a simple equation of William Davis' sufferings with those of Christ (in contrast to Suttor: 20). That would be blasphemous. Yes, it is an Ecce Homo statue but no, it is not a depiction of Christ being or having just been flogged as both Luck and Whitaker claim. ${ }^{27}$ Such images were titled Christ at the Column, ${ }^{28}$ and they had a focus on expressing immediate physical pain, embodying the suffering humanity of Christ. They do not show the resigned suffering of Davis' statue. Moreover, Christ at the Column statues carry no crown of thorns; the crowning by Roman soldiers to spite Jesus' claim to royalty comes after the flagellation. In contrast, an Ecce Homo iconography shows this claim of "Christ the King" explicitly in the crown of thorns, a claim which featured strongly in late eighteenth century debates about a publically Catholic society, be that in the Vendée rising, or in the eighteenth century Irish epithet for Jesus: "King of Sunday"29 (Carroll: 25).

The Ecce Homo iconography further carries the message of corrupt Roman authorities in the normally absent but implied Pontius Pilate whose Vulgate version quote about Christ of John 19:5 is the name given to these statues, "behold the man". It rings an eerie echo of the self-styled Augustan rule of the Georgians, of Britain as the new Rome and of its global empire. The statue thus points to a violent miscarriage of justice by imperial authorities, and it points to this miscarriage being, in an Irish Catholic context, relevant to the notion of Christ as King, the King of Sunday. As such, it ties in with the traditional claim that William Davis was flogged for refusing to attend the Anglican church service ${ }^{30}$ which is heightened but also simplified by the inscription's more generalizing claim of suffering for his faith. More

26 Cf. Office of the UN Special Adviser on the prevention of genocide www.un.org/ar/preventgenocide/ adviser/pdf/osapg_analysis_framework.pdf additionally lists the forcible transfer of the children of the suppressed group to another group, which echoes of King's orphanage project coinciding with the time frame of the three first attempts and the actual rebellion.

27 "The Ecce Homo statue of the scourged Christ was clearly intended to symbolise the suffering of the Catholics, and its recipient was reputed to have been flogged and locked in the black hole for refusing to attend protestant services"; Whitaker (1996): 37; also: Luck: 109.

28 Christ at the Column with wounds of crucifixion, thorns (sometimes also weapons of crucifixion and ministering angels): Misericordia medieval tradition.

29 Traditional name of wells: $\mathrm{Ri}$ an Domhnaigh (Ri-an-Dom-knee) dedicated to Christ but also topic of a poem by Tomás Rua Ó Súilleabháin (1785-1848) from Kerry, hedgeschool master and supporter of Daniel $\mathrm{O}^{\prime}$ Connell, 13 in 1798, died in the famine.

30 Disputed on general terms by Whitaker: 37; compare to Order of 4.10 .1800 confirming obligatory attendance and sabbath observance, \& report 1.03.1804 adding "by respectfully referring your Lordship to the list of punishments inflicted during the year 1803, which I beg to offer as a proof that the morals of the inhabitants and punishment of vice is not neglected". Qtd. in Yarwood: 82. 
importantly, the complexity of the statue's iconography voices a coded counterclaim to the Anglican church's monopoly in colonial New South Wales.

\section{Conclusion}

It is in this triple causality that the long-term impact of the rebellion at Castle Hill on Australia can be found - an impact very likely not intended, as the demand for "a ship home" seemed to dismiss the colonial project in its entirety. ${ }^{31}$ At the back of demands for justice stands the assurance of a right to fair trial, of habeas corpus, and thus of a long-lasting impact of English common law in Ireland which was extended by the United Irishmen to their expectations of the Australian colony. At this point, colonial New South Wales fell far short of such expectations, but the eventual abolition of the military jurisdiction and the growth of law in Australia can be also seen as a form of abjection of the judicial abuses evident in the Castle Hill Rebellion.

The other long-term consequence of the cry for liberty or death was the emergence of a liberal Catholicism from the underground in the 1820s, a Catholicism which did indeed employ Enlightenment discourses of liberty and universal religious toleration (Gascoigne: 31), before, in its turn, giving way to the rise of ultramontane and Irish national Catholicism that still dominates Australian perceptions of the Irish in the nineteenth century.

\section{Bibliography}

Alexander, Jeffrey, 2011. "Toward a Cultural Theory of Trauma", in: Jeffrey K. Olick, et al., eds., The Collective Memory Reader, 307-309.

Atkin, Nicholas, and Frank Tallett, 2003. Priests, Prelates and People: A History of European Catholicism, 1750 to the Present. London: Tauris.

Bartlett, Thomas, and Keith Jeffery, eds., 1996. A Military History of Ireland. Cambridge: Cambridge University Press.

Bartlett, Thomas, 1996. “Defence, Counter-Insurgency and Rebellion: Ireland 1793-1803”, in: Thomas Bartlett and Keith Jeffery, eds., A Military History of Ireland, 247-239.

Beiner, Guy, 2011. "Modes of Memory: Remembering and Forgetting the Irish Rebellion of 1798", in: Oona Frawley, ed., Memory Ireland, Vol. 4.1: History and Modernity, 66-82.

Boyce, D. George, and Alan O'Day, eds., 1996. The Making of Modern Irish History: Revisionism and the Revisionist Controversy. New York: Routledge.

Callaghan, Thomas, 1844. Acts and Ordinances of the Governor and Council of New South Wales, and Acts of Parliament, Enacted For, or Applied To, The Colony, with Notes and Index. Sydney: John Row.

Carroll, Michael P., 1999. Irish Pilgrimage, Holy Wells, and Popular Catholic Devotion. Baltimore: John Hopkins University Press.

Commonwealth of Australia, 1914. Historical Records of Australia. Series I: Governor's Despatches To and From England. Vol. 2-4. Sydney: The Library Committee of the Commonwealth Parliament.

Congregatio de Propaganda Fide, 1907. Collectanea S. Congregationis de Propaganda Fidei seu Decreta Instructiones Rescripta pro Apostolicis Missionibus, 2 Vols. Rome: Typographia Polyglotta.

Conner, Clifford C., 2000. Colonel Despard: The Life and Times of an Anglo-Irish Rebel. Pennsylvania: Combined Publishing.

31 O'Farrell: 38, "against the very fact of Australia". 
Connolly, S. J., 1996. “Eighteenth-Century Ireland: Colony or ancién regime?", in: D. George Boyce and Alan O'Day, eds., The Making of Modern Irish History: Revisionism and the Revisionist Controversy, 15-33.

Corish, Patrick J., ed., 1971. A History of Irish Catholicism, Vol. 6. Dublin: Gill \& Macmillan.

Desan, Suzanne, 1990. Reclaiming the Sacred: Lay Religion and Popular Politics in Revolutionary France. Ithaca: Cornell University Press.

Dupuy, Roger, 2005. La République Jacobine. Terreur, Guerre et Gouvernement Révolutionnaire, 1792-1794, Nouvelle histoire de la France contemporaine, Vol. 2. Paris: Éditions du Seuil.

Elliott, Marianne, 2012. Wolf Tone. Liverpool: Liverpool University Press.

Frawley, Oona, ed., 2011. Memory Ireland, Vol. 4.1: History and Modernity. New York: Syracuse University Press.

Garvin, Tom, 1987. “Defenders, Ribbonmen and Others: Underground Political Networks in Pre-Famine Ireland", in: Charles H. E. Philpin, ed., Nationalism and Popular Protest in Ireland, 219-244.

Gascoigne, John, and Patricia Curthoys, 2002. The Enlightenment and the Origins of Australia. Cambridge: Cambridge University Press.

Hachey, Thomas E., and Lawrence J. McCaffrey, 2010. The Irish Experience Since 1800: A Concise History. New York: M. E. Sharpe.

Hempton, David, 2003. "Established Churches and the Growth of Religious Pluralism: A Case Study of Christianisation and Secularisation in England since 1700", in: Hugh McLeod and Werner Ustorf, eds., The Decline of Christendom in Western Europe, 1740 2000, 81-93.

Himmelfarb, Gertrude, 2004. The Roads to Modernity: The British, French and American Enlightenments. New York: Knopf.

Hughes, Robert, 1988. The Fatal Shore: The Epic of Australia's Founding. New York: Vintage.

Joes, Anthony James, 2004. Resisting Rebellion: The History and Politics of Counterinsurgency. Lexington: The University Press of Kentucky.

Juergensmeyer, Mark, 2003. Terror in the Mind of God: The Global Rise of Religious Violence. Berkeley: University of California Press.

Karskens, Grace, 2009. The Colony: A History of Early Sydney. Crows Nest, NSW: Allen \& Unwin.

Keneally, Thomas, 2006. A Commonwealth of Thieves: The Improbable Birth of Australia. New York: Doubleday.

King, Jonathan, and John King, 1981. Philip Gidley King: A Biography of the Third Governor of New South Wales. Melbourne: Methuen.

Luck, Peter, 1992. Australian Icons: Things That Make Us What We Are. Melbourne: Heinemann.

MacManus, Antonia, 2004. The Irish Hedge School and Its Books, 1695-1831. Portland: Four Courts Press.

McBride, Ian, 2009. Eighteenth Century Ireland: The Isle of Slaves. Dublin: Gill and Macmillan.

McGovern J. J., and Patrick J. O'Farrell, 1971. Australia, in: Patrick J. Corish, ed., A History of Irish Catholicism, Vol. 6.

McLeod, Hugh, and Werner Ustorf, eds., 2003. The Decline of Christendom in Western Europe, 1740 - 2000. Cambridge: Cambridge University Press.

Moore, Tony, 2010. Death or Liberty: Rebel Exiles in Australia, 1788 - 1868. London: Murdoch Books.

Nolan, Emer, 2007. Catholic Emancipations: Irish Fiction from Thomas Moore to James Joyce. Syracuse, NY: Syracuse University Press.

O'Farrell, Patrick, 2000. The Irish in Australia: 1788 to the Present. Indiana: University of Notre Dame Press.

Olick, Jeffrey K., et al., eds., 2011. The Collective Memory Reader. Oxford: Oxford University Press.

Philpin, Charles H. E., ed., 1987. Nationalism and Popular Protest in Ireland. Cambridge: Cambridge University Press.

Quinn, Richard, 2008. Samuel Marsden: Altar Ego. Wellington: Dunmore Publishing.

Ranelagh, John O'Beirne, 2004. A Short History of Ireland. Cambridge: Cambridge University Press.

Reece, Bob, 2001. The Origins of Irish Convict Transportation to New South Wales. London: Palgrave.

Silver, Lynette, 2002. The Battle of Vinegar Hill: Australia's Irish Rebellion. Sydney: Watermark Press. 
Statham, Pamela, ed., 1992. A Colonial Regiment: New Sources Relating to the New South Wales Corps. Canberra: National Library of Australia.

Suttor, T. L., 1965. Hierarchy and Democracy in Australia 1788 - 1870: The Formation of Australian Catholicism. Melbourne: Melbourne University Press.

Symes, James G., 1979. The Castle Hill Rebellion of 1804. Hill District Historical Society.

The Book of Common Prayer, 2006. Oxford: Oxford University Press.

Turbet, Peter, 2011. The First Frontier: The Occupation of the Sydney Region, 1788 to 1816. Dural, NSW: Rosenberg.

Watson, Frederick, 1914ff. Historical Records of Australia. Series I, Volume 3 \& 4 . Sydney: Library Committee of the Commonwealth Parliament.

Whelan, Kevin, 2004. "The Green Atlantic: Radical Reciprocities between Ireland and America in the long Eighteenth Century", in: Kathleen Wilson, ed., A New Imperial History: Culture, Identity and Modernity in Britain and the Empire, 1660 - 1840, 216-238.

Whitaker, Anne-Maree, 1994. Unfinished Revolution: United Irishmen in New South Wales, 1800 - 1810. Sydney: Crossing Press.

Whitaker, Anne-Maree, 1996. “'Ecce Homo': William Davis, James Dempsey and Father Jeremiah O'Flynn", Journal of the Australian Catholic Historical Society, 17, 29-43.

Wilson, Kathleen, ed., 2004. A New Imperial History: Culture, Identity and Modernity in Britain and the Empire, 1660 - 1840. Cambridge: Cambridge University Press.

Wiltgen, Ralph M., 2010. The Founding of the Roman Catholic Church in Oceania, 1825-1850. Eugene, OR: Pickwick Publications.

Woods, Gregory D., 2002. A History of Criminal Law in New South Wales. Vol. 1: The Colonial Period, 1788-1900. Annandale: Federation Press.

Yarwood, A. T., 1996. Samuel Marsden: The Great Survivor. Melbourne: Melbourne University Press.

Zerubavel, Yael, 2011. "Recovered Roots: Collective Memory and the Making of Israeli National Traditions", in:Jeffrey K. Olick, et al., eds., The Collective Memory Reader, 237-241.

\section{Web Sources}

Bubacz, Beryl M., 2007. The Female and Male Orphan Schools in New South Wales, 1801 1850. Dissertation Thesis University of Sydney. pdf; ses.library.usyd.edu.au/bitstream/2123/2474/1/01BubaczThesisPart1Chs1\%262.pdf, accessed 20.01.2018.

Cathecism of the Council of Trent, 1829. Transl. Rev. J. Donovan. Baltimore: Lucas Brothers. archive.org/stream/thecatechismofth00donouoft/thecatechismofth00donouoft_ djvu.txt, accessed 28.11.2018.

Morley, John, 2003. "Convict Priest was in favour - and out". Catholic Weekly (11th May) http://www.catholicweekly.com.au/03/may/11/03.html, accessed 19.9.2014.

,2008. "How the Church found its way to the Great South Land". Catholic Weekly (15th July) www.catholicweekly.com.au/, accessed 19.9.2014.

Parsons, Vivienne, 1966. "Dixon, James", in: Australian Dictionary of Biography, Vol. 1. Melbourne: Melbourne University Press. adb.anu.edu.au/biography/dixon-james-1980, accessed 19.9.2014.

Saltmarsh, David, 2005. “Transforming the Female Orphan School”. Paper presented at the AARE 2005 Conference. PDF www.tjmf.org.au/data/publications/2005/sal05288.pdf, accessed 13.10.2017. 